Article

\title{
The Role of Manufacturing in Sustainable Economic Development: A Case of Guangzhou, China
}

\author{
Wei Li ${ }^{\circledR}$, Desheng Xue * and Xu Huang \\ Research Center for Urban and Regional Studies, Department of Geography and Planning, \\ Sun Yat-sen University, Guangzhou 510275, China; liw26@mail2.sysu.edu.cn (W.L.); \\ huangx253@mail.sysu.edu.cn (X.H.) \\ * Correspondence: eesxds@mail.sysu.edu.cn; Tel.: +86-20-8411-2738
}

Received: 23 July 2018; Accepted: 24 August 2018; Published: 27 August 2018

\begin{abstract}
Economic development is the natural requirement of urban sustainability. Faced with uncertainty in society, including economic crisis and risk, the ability to reduce the stress and increase the security of economic life should be considered. World cities, deeply impacted by globalization and urbanization, deserve more attention with respect to the economic dimension of sustainable development. This study explored the role of manufacturing in the sustainable economic development of world cities, based on research in Guangzhou, China. This paper applies the grounded theory method, whereas data collection was performed through in-depth semi-structured interviews and field observations. This research found industrial interactions between manufacturing and a variety of relevant advanced producer services facilitate industrial upgrading and diversity, which exert positive effects on the city's economic dimension of sustainable development.
\end{abstract}

Keywords: manufacturing; sustainable economic development; grounded theory method

\section{Introduction}

Sustainability has attracted an unprecedented upsurge in interest with respect to human development. The United Nations Commission on Sustainable Development (CSD) constructed a sustainability indicator framework with 15 goals and about 140 indicators which covered economic, social, environmental and institutional aspects of sustainable development in 2001 and changed to focus on three aspects on economic, social and environmental dimensions with 17 goals in 2016 [1,2]. Following the new changes, researchers have attempted to apply various indices to describe or measure urban sustainability [3-5]. Strezov has compared one of nine main indices for measuring the economic, social, and environmental dimensions of sustainable development and pointed out that sustainable development valued economic dimension was the lowest [5]. However, these three dimensions are related to and affect each other. However, economic development is the natural requirement of sustainability [6]. Currently, in the global economy, we are faced with not only the uncertainty of the environment, but also the uncertainty of society, including economic crisis and risk [7]. The ability to reduce the stress and increase the security of economic life should be considered when we mention sustainable economic development [8]. Particularly, for world cities, which are deeply impacted by globalization and urbanization, sustainable economic development deserves more attention.

Since Friedmann's $[9,10]$ and Sassen's [11,12] initial work, world cities have emerged as the most dominant vanguard incorporated into the global economy. The control and command function is one of the robust integral parts of world city formation, which is closely associated with the corporate headquarters status of some dominant multinational companies and key nodes in advanced producer service industry [13,14]. Followed closely by the concept of "space of flow" [15], Globalization and World Cities (GaWC) researchers adopted the interlocking world city network (WCN) model to 
measure the inter-city relations. The formations of inter-city relations have presented in various forms, such as transportation network perspective [16], knowledge collaboration [17], and corporate networks $[18,19]$. In the economic perspective, more studies take the approaches on corporate networks. Most scholars use data on advanced producer services, while few use data on manufacturing firms to describe world cities' production relations [20,21]. For world cities in the global south, manufacturing's role lacks sufficient attention. Therefore, we follow the perspective of manufacturing and attempt to raise attention on the importance of manufacturing sector development after the global economic crisis.

Guangzhou, located in the Pearl River Delta, southern China, is the third world city in mainland China, after Shanghai and Beijing according to GaWC global city ranking list. Numerous studies show that Guangzhou has been experiencing the process of industrialization and tertiarization [22-24]. With the rapid growth of advanced producer service activities, Guangzhou acts as a hub in the regional service market and links the region with the broader service networks in China and in the globe [19]. Despite more value added in service sectors, manufacturing has kept increasing during the last 30 years. In 2016, the increase rate of industrial added value in Guangzhou (6.5\%) was higher than that of national level (6\%), and also higher than Beijing (5.1\%) and Shanghai (1.1\%) [25].

In this paper, we aim to provide analysis on urban scale bringing together crucial theoretical insights from manufacturing in world city and an integrated framework with sustainable economic development by answering the following research question:

How does manufacturing sector affect the world city's sustainable economic development? Providing an answer to this question is more complicated by the fact that Guangzhou has been undergoing the process of industrial upgrading from labor-intensive light industry to capital-intensive and technique-intensive heavy industry, which is added to a series of industrial actors being integrated. Acknowledging this complexity embedded in the analysis of the process and mechanism of manufacturing's role in urban economic sustainable development, a research design based on Grounded Theory Method (GTM [26]) was selected. In this inductive approach, explanation of the research question is not limited to the existing theoretical perspectives. Rather, the GTM allows the explanations to emerge from the data which are reflected in the broadness of the research question.

With this background, the structure of the paper is as follows: the next section discusses the notion of sustainable economic development and manufacturing's role in world city. Subsequently, the methodology including the grounded theory method and the rationale for choosing Guangzhou as the study area are outlined. Section 4 is the analysis of GTM results exploring the role of manufacturing in the world city's economic sustainable development. Finally, we conclude by discussing the limitations of the study, further research and by summarizing conclusions on generally.

\section{Literature Review: Sustainable Economic Development and Manufacturing in World Cities}

\subsection{Sustainable Economic Development and Industrial Development}

There are various approaches to the definition and characterization of urban economic sustainability. The United Nations Commission on Sustainable Development (CSD) mainly measured the sustainable economic development by theme indicators as economic structure and development, and consumption and production patterns $[1,2,27]$. Basic economic growth is generally measured by GDP per capita, investment share in GDP, and a balance of trade in goods and service [2,28,29]. In terms of consumption and production patterns, resource usage efficiency and cost, the intensity of land, water and energy usage are generally discussed [30-35]. Recently, there is more research on industrial upgrading and diversity with economic sustainability [36-38]. The development of industrial upgrading and diversity are considered as long-term fundamental factors in strengthening economic stability $[39,40]$.

The industry upgrading linking with sustainable economic development could be viewed as an effective approach to improve the production efficiency, energy saving and emission reduction, which is linking with green industries and low-carbon industries [41-44]. Fu et al. enriched the understanding 
of industrial green transformation in China and highlighted the progress of the knowledge-intensive industry [44]. Zhou et al. established the internal link between upgrading of industrial structure and spatial optimization based on the water environment carrying capacity [45]. Gu et al. developed an inexact fuzzy stochastic programming method to optimize industrial structures and achieve economic sustainability in a resource-based city [46]. In addition, researchers showed that industrial diversity is positive for economic growth and minimizing employment instability in some regions [47-55], which is linking with economic resilience [54,56]. Development economists also use the term diversification. In our research, we make no distinction between diversity and diversification, as if these terms were interchangeable [50]. Diversity refers to the variety of economic activity which reflects differences in economic structure [50,57]. Ernst presented that Korea's industrial upgrading has integrated with the provision of advanced support services for technology innovation on production design [58]. These close interactions strengthened the technological capabilities of enterprises to lower the use of energy and resource. Chen and Chien demonstrated that dynamic relationships between industrial sectors could improve the effective production and reduce material sourcing, energy consumption and sewage discharge [59].

The existing research has built up the link with industrial upgrading and diversity with economic dimension in sustainability. Nevertheless, the mechanism and the process of the manufacturing's role in these two aspects have not been explained clearly. Especially, at firm level on the urban scale, the empirical theory is not enough to explain the Guangzhou case. Taking the example of industrial interaction between manufacturing and advanced producer service, we found the innovation of manufacturing could stimulate the innovation of advanced producer service, which facilitates to lower the immediate cost, save energy and resource [60,61]. However, manufacturing interacts with advanced producer service, with what kinds of approaches and what kind of incentives need to be further discussed.

Therefore, in our study synthesizing previous research, selected GMT to explore manufacturing's role in industrial upgrading and industrial diversity between advanced manufacturing and advance producer service (Figure 1).

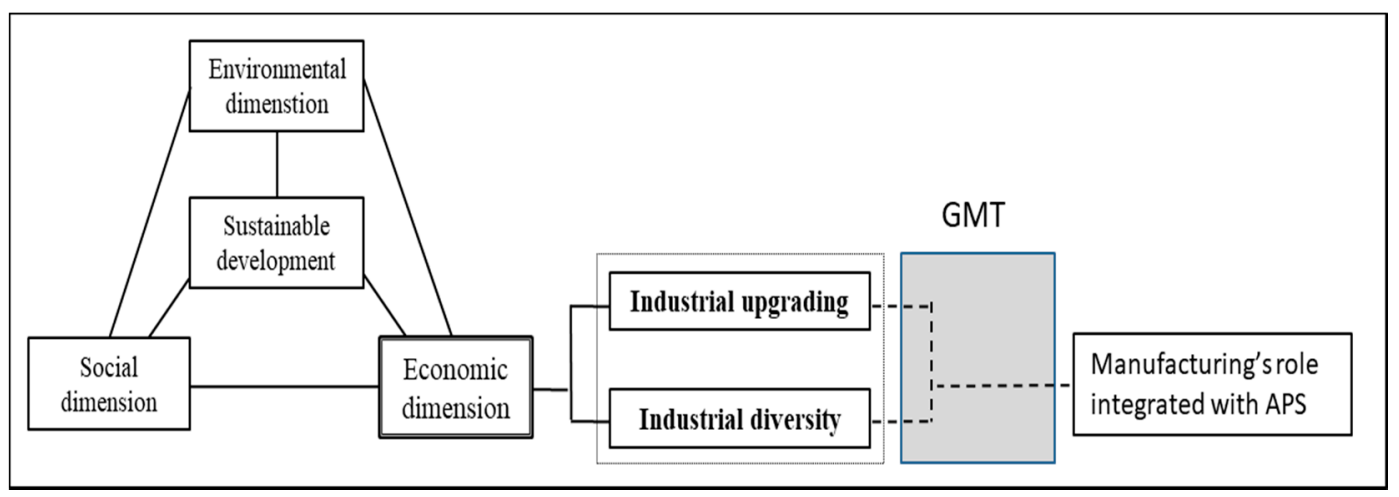

Figure 1. Selected themes of sustainable economic development and framework of the research. Source: made by authors.

\subsection{Manufacturing in World Cities}

In terms of manufacturing's role in world city, there are three scales to illustrate: the historical scale, regional scale, and global scale. From these studies, we investigate that manufacturing not only exists in world cities, but also plays a significant role in the development process to connect the world with dynamic industrial upgrading. Therefore, it is meaningful to consider the role of manufacturing in world cities' sustainable economic development.

First, there is historical scale. Friedmann has pointed out that the emergence of the world city was attributed primarily to the new international division of labor with main function of control and 
management power [9]. Historical geographers opposed and argued that before the new international division of labor, manufacturing was the main drive for world cities. One of the precedent findings was from Rodriguez and Feagin. Rodriguez and Feagin chose three pairs of cities, Amsterdam-Leiden (during the period of Dutch Hegemony), London-Manchester (during the period of British hegemony) and New York-Houston (during the period of US hegemony), to illustrate the dynamics of world city formation with financial center and industrial center, respectively, as particular types of urban specialization [62]. In these three pairs of world cities, global industrial cities could be world cities with advanced technique connecting other cities in the world. Abu-Lughod chose New York, Chicago and Los Angles to present industrialization's extensive influence on urban globalization in social and spatial patterns [63]. In his findings, manufacturing's impact in history could not be neglected.

Second, there is regional scale. Except for the capital economy, world cities under the developmental state showed different economic features and performance. Hill and Kim demonstrated that Tokyo and Seoul represent different types of world cities because of their industrial policies and state institutions [64]. Distinguished from New York, Tokyo and Seoul have not experienced severe manufacturing decline. On the contrary, they maintain high-tech industrial growth and those productions are concentrated in cities $[64,65]$. Taipei and Singapore also show similar industrial structures [66,67]. Though tertiary industry has been in a dominant position, they still grasp leading positions on some high-tech manufacturing. These studies have proven that advanced manufacturing has played a significant role in current world cities. Unfortunately, the main arguments of these studies manifested the role of the developmental state associated with various industrial structures, not on the industrial effects.

Third, there is global scale. From the global perspective, some researchers indicated the diversified inter-city relations through manufacturing [20]. Krätke chose the firm-link from "automotive industry", "technology hardware and equipment", and "pharmaceutical and biotechnology" to present industries' connections across the world $[20,68]$. Currently, some research on Chinese cities has proven multiple pathways to world city formation [69,70]. Empirically, existing literature on Chinese world city centers on Hong Kong, Beijing, and Shanghai. These studies revealed the process of economic transformation from a manufacturing-led economy to service-led [71-75]. However, they paid less attention on the effect of industrial upgrading and diversity on economic sustainability.

\section{Methodology and Study Area}

\subsection{Methodology}

Grounded theory method (GTM) is a qualitative research methodology explicitly focused on generating new theoretical insights grounded in a systematic data collection and analysis process. Developed by Barney Glaser and Anselm Strauss in 1967, the thrust behind the GTM movement was a desire to bridge the gap between theoretically uninformed empirical research and empirically uninformed theory [26,76-78]. In its nascent form, grounded theory can be described as "the discovery of theory from data" and "theory-discovery methodology" with three attributes: the process of data coding, the process of theoretical sampling and the integration of literature [26]. Strauss and Corbin [76,79], and Charmaz [80] modified the process of theoretical sampling from Classical grounded theory and developed Straussian grounded theory and Constructivist grounded theory, respectively. In our research, constructivist grounded theory is the most suitable remodeling of grounded theory to interpret the economic process. Constructivism assumes a relativist epistemology, acknowledges the mutual creation of knowledge by the viewer and the viewed, and aims towards interpretive understanding of subjects' meanings in the historical, social, and situational conditions of its production [81]. Therefore, researchers who use constructivist grounded theory are often more focused on how subjective experiences can be abstracted to form theoretical insights regarding collective understandings or relationships amongst actors. In addition, the credibility of grounded theory method is consistent with its inductivity origins, which means the systematic comparison for 
the key ideas emerging through the data should be validate for the studied experience and related substantive areas [82].

In the topic of sustainability, researchers have adopted GTM to explore specific discussions $[77,78]$. We followed Charmaz's approach to GTM as open coding, selective coding and theoretical coding, where the aim of analysis is the framework building based on interview and observation materials to explore the industrial interaction between manufacturing and advanced producer service.

\subsubsection{GTM Data Collection}

To deeply understand the process of industrial relations, we chose the automobile industry and advanced producer service to unpack the industrial link. The automobile industry is one of the three pillar industries in Guangzhou (Figure 2). In terms of gross output value, after 2006, the automobile industry has been one of the largest pillar industries in Guangzhou. The output value in 2016 was 434.63 billion yuan, which is nearly twice the second pillar industry, electronic appliance manufacturing. In addition, the nature of automobile industry has wide ranges of forward and backward industrial relations. Following the definition of advanced producer service from $\mathrm{GaWC}$, we defined the advance producer service as banking, insurance, accounting, advertisement, law, management consultancy and logistics $[83,84]$.

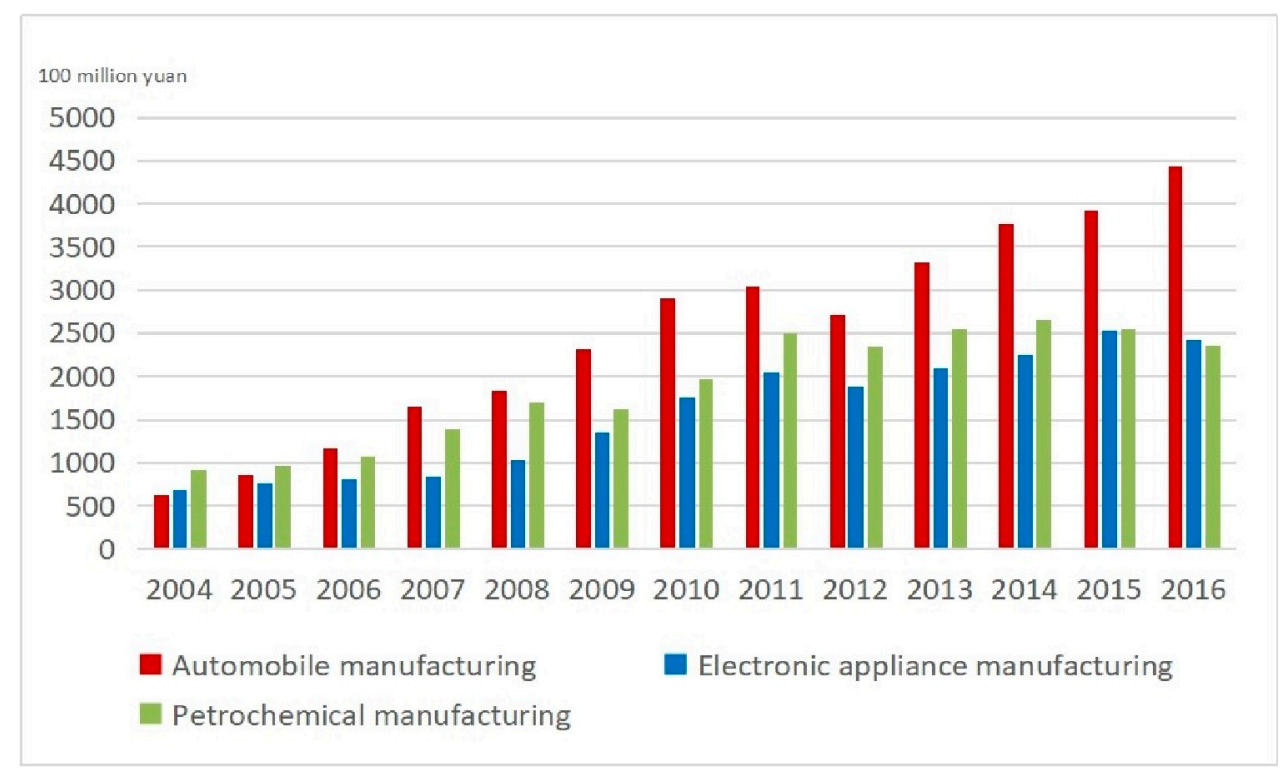

Figure 2. Three pillar industries in Guangzhou. Source: [25].

We drew on the intensive interview format as one of the main methods of gathering rich data in constructivist GTM. Qualitative data were collected between September 2013 and February 2017, as shown in Table 1, with 46 semi-structured interviews covering: (a) automobile manufacturers including complete vehicle manufacturers and spare parts manufacturers; (b) advanced produce services which are related to the automobile industry; (c) industrial associations which are servicing for the automobile industry; and (d) local government officials. Each interview lasted about 1.5-3 h with informed interview questions. Interviews were conducted in the workplaces of those interviewed. Although the sample size was limited, interviewers' inclusion criteria were rigorously designed. Therefore, the sample was representative and comprised reliable data. The major research questions of this fieldwork contained four sections:

(1) General information about the company: history, activities, etc.

(2) Information on production: products, trends, factors diving the evolution. 
(3) Information on advanced producer service outsourcing: nature, partnership, goals, factors influencing cooperation, etc.

(4) Information on collaboration with other industrial actors and local governments

Table 1. Characteristics of the research interviewees.

\begin{tabular}{cccccc}
\hline Unit & Senior Manager & Director & Section Chief & Project Leader & Total \\
\hline Manufacturers & 4 & 6 & 4 & 0 & 14 \\
Related advanced producer service & 0 & 10 & 6 & 4 & 20 \\
Industry Association & 0 & 0 & 0 & 5 & 5 \\
Government & 0 & 0 & 7 & 0 & 7 \\
\hline Total & 4 & 16 & 17 & 9 & 46 \\
\hline
\end{tabular}

The interview questions were related to industrial link, globalization, and industrial upgrading (Appendix A). Interviewees are experienced middle-level and above managers in firms, industrial associations, and governmental agencies. All participants approved audio taping and transcription, which produced a total of $70 \mathrm{~h}$ and over 500 pages of transcripts.

\subsubsection{GTM Data Analysis}

After collecting the required data, researchers analyzed along the lines of the constructivist GTM with the process of open coding, selective coding and theoretical coding (Figure 3 and detail example in Appendix B). Line-by-line coding of the data is required to ensure its comprehensive synthesis, so that potential emergent themes can be identified [85]. In open coding, the codes were simple and used to lower level of abstraction. Nearly 500 initial codes were transcribed by the researchers. In selective coding, higher frequency and higher importance formed the concepts. About 100 focus codes were categorized into groups. The theoretical coding in the constructivist grounded theory is similar to determine the dimension of categories which shape the analysis process. Seven categories and main parts of focus codes are listed in Appendix C. The researchers constantly adopted the constant-comparison procedure between data and emerging categories from the three coding stages, which compared data with data, codes with data, codes with codes, codes with categories, and categories with each other. During open coding, some consistent patterns were identified, for example, increasing outsource of advanced producer service in manufactures. Likewise, the outsource of logistics, advertisement and advanced cooperation partners in accounting were identified during each of the coding phases and through constant comparison the prevalence of these viewpoints could be established as industrial linkage and interaction. An action-oriented paradigm was used to further sort the data and developed causal relationships between conceptual categories to describe "how" the interaction with manufacturing and related advanced producer service happened. Two core categories were found from the data which helped to develop and understand the manufacturing's role in economic sustainability. These categories are as follows:

(1) Incentives for industrial interaction

(2) Process of industrial interaction

Throughout this three-part coding process, memos during the interviews were also used to shape concepts and their properties. Researchers tested the two core categories by reanalyzing them through the comparison of findings alongside more focused literature searchers. It was found to underpin the theoretical insights of manufacturing's role in economic sustainability and directed the research towards industrial upgrading and diversity in relation to sustainable economic development. Without following constructivist grounded theory methods, it is unclear the mechanism and process of industrial interaction between automobile manufacturing and advanced producer service in Guangzhou case behind the general economic development trends. 


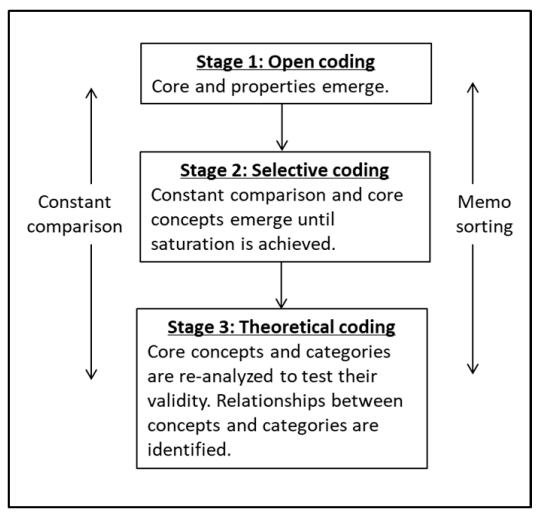

Figure 3. Diagram of constructivist grounded theory approach used in this study. Source: Adapted from [86].

\subsection{Study Area}

Why choose Guangzhou? A brief profile of Guangzhou is drawn with some basic data. Firstly, Guangzhou is the third world city in mainland China, after Shanghai and Beijing, with a total population of $8.5 \times 10^{7}$ with permanent registered households and $8.8 \times 10^{4}$ foreigners registered. The city is the central city of the Pearl River Delta, which is the major base of the foreign-oriented economy in China, known as the World Factory [87]. Secondly, Guangzhou has diversified economy. On the one hand, it has a long history of commercial culture as an international trade port city in the world. On the other hand, it has the well-developed industrial system of southern China with 35 industrial sectors (the national total is 41). Thirdly, Guangzhou is the preferred city to develop an export-oriented economy and internationalized itself by industrialization [87]. In 1979, as the capital of Guangdong province, Guangzhou was one step ahead to attract large amounts of foreign investments from Hong Kong, Taiwan, and Macau. Nearly $80 \%$ of total foreign investment in Guangdong province was concentrated in the city at that time. In 1984, the central government further opened 14 coastal port cities, including Guangzhou, to have more preferential policies to attract foreign mega-projects. The Guangzhou Economic \& Technological Development Zone was established at that time, as the first national Development Zone, aimed at developing modern industry, to utilize foreign capital and to improve the value of export products. Presently, the city has three national economic and technological development zones, four provincial industrial parks, and 15 municipal advanced manufacturing bases.

Guangzhou's manufacturing is experiencing industrial upgrading from labor-intensive light industry to knowledge-intensive and capital-intensive heavy industry [23,24]. Figure 4 presents changes on the industrial structure from 1978 to 2015. Over time, the light and heavy industries have maintained steady growth in the gross output value and, after 2004, heavy industry has exceeded light industry. In 2016, the gross output value of heavy industry was 1358 billion yuan, twice that of light industry [25]. From 1990 to 2016, the annual average growth rate of heavy industry was 19.3\%, nearly $5 \%$ higher than that of light industry [25]. The gross value of advanced manufacturing has increased rapidly. In 2000, Guangzhou municipal government confirmed automotive manufacturing, petrochemical industry, and electronic appliance manufacturing as the three pillar industries. From 2010 to 2015, these three pillar industries' proportions of all industrial enterprises above designated size, in terms of the number of units, ranged from $19.46 \%$ to $23.83 \%$; in terms of employed persons, from $26.07 \%$ to $30.95 \%$; in terms of gross output value, from $48.01 \%$ to $48.25 \%$; and in terms of total profits, from $56.05 \%$ to $64.29 \%$ [25]. There is no doubt that advanced manufacturing is guiding the development of industry. We could clearly find the increasing trend of advanced manufacturing in Guangzhou (Figure 5). Figure 6 explicitly illustrates the fundamental state of environment conditions in Guangzhou. From the changes on volume of industrial sulfur dioxide emission, and industrial soot and dust emission, we found that the industrial emission has reduced. 


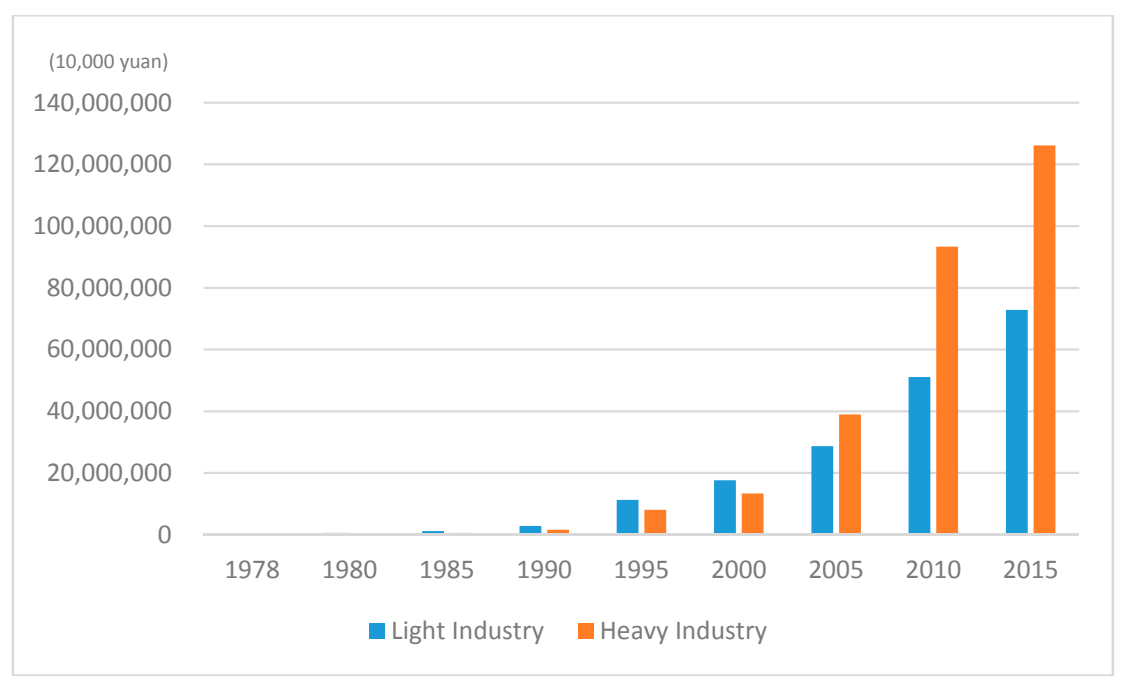

Figure 4. Industrial structure of Guangzhou in main years (1978-2015). Source: [25].

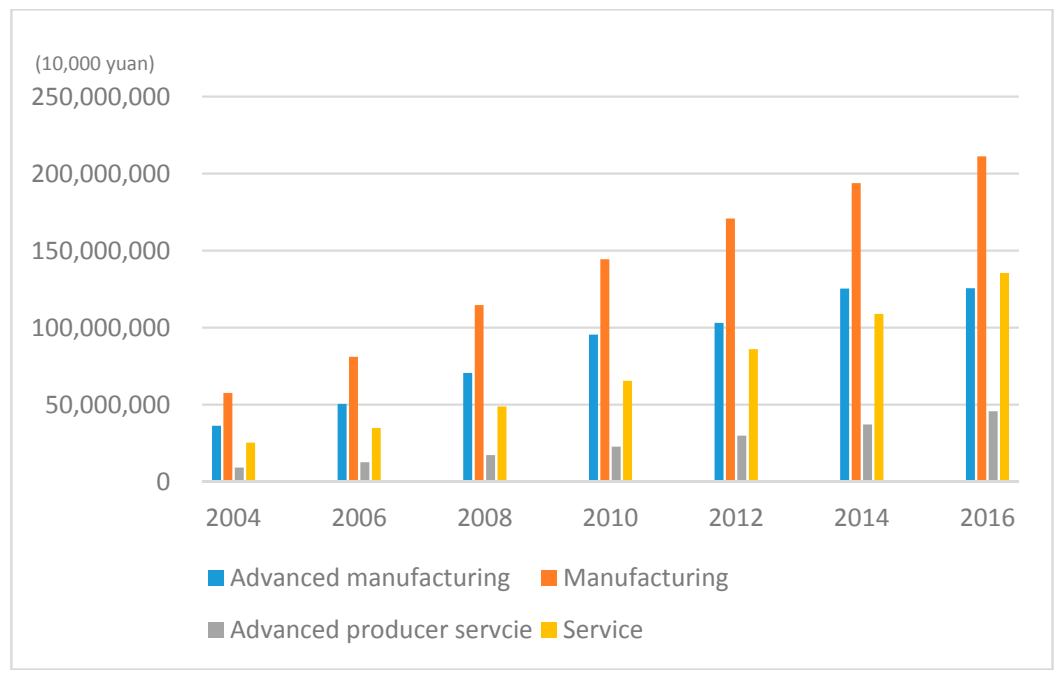

Figure 5. Gross value of advance manufacturing in manufacturing in main years. Source: [25].

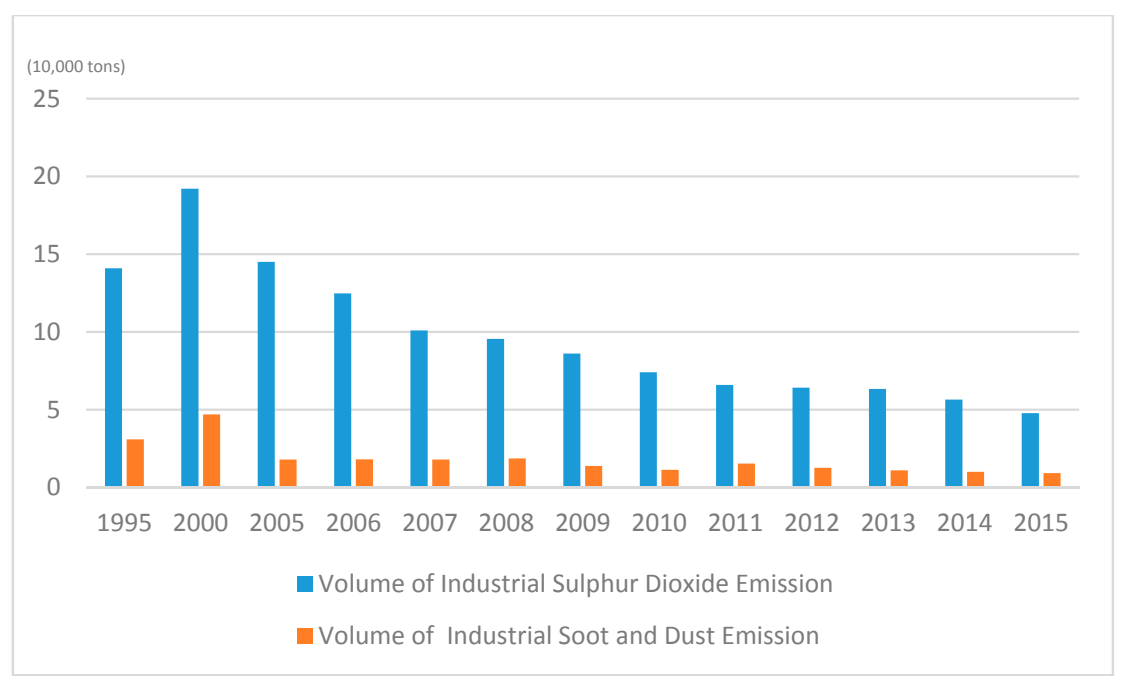

Figure 6. Fundamental state of environment protection in main year. Source: [25]. 


\section{Results}

4.1. Mechanism for Industrial Upgrading from the Perspective of Manufacturing Development Incentive for Advanced Producer Service Development

The results demonstrate that the most important contextual factors for incentive for advanced producer service are the demand for production expansion, requirement for market competition and selection of "localization" strategy.

The demand for production expansion is characterized by a series of increases and expansions in production output, assembly lines, and products sales. Especially for the complete vehicle manufacturers, in the initial stage for the industrial development, they prefer to outsource services which are not their core businesses to help them focus on production expansion to reach the effect of scale and balance the cost. In this context, in accordance with the increase in branches and plants for manufacturers, advanced producer services also increase rapidly.

The requirement for market competition has three concepts that are competition for product quality, technique and service. Product quality and technique are the nature of competitions between manufacturers, however, the services during the production sales and after sales are new categories which customers focus on. The feedbacks from manufacturers reflect that $4 \mathrm{~S}$ stores become popular for local customers to experience the process of purchasing and after-sale services. More complete vehicle manufacturers invest and strengthen the cooperation with $4 S$ stores to shape a good enterprise image with emphasizing both the production and service for customers.

The selection of localization strategy is various depending on the enterprisers. In Guangzhou case, the leading industrial partners of automobile are from Japanese multinational companies, and one of the successful strategies for them to conquer international market is the "localization" strategy. Therefore, the headquarters required branches in Guangzhou to implement the "localization" strategy which demonstrate as the deep cooperation with local actors including local advance producer servicer and local manufacturers. From the perspective of local spare parts manufactures, they appreciated the cooperation with Japanese manufacturers which enhanced their production ability initially. The implementation of localization strategy leads to the increasing localization rate of spare parts and advanced producer services.

The following quotations capture the demand for cooperation with advanced producer service from the perspectives of producers (TOY.1):

"As we would establish another manufacturing base, our production capacity would increase twice than before. We strongly recommended the logistics of Material Center inside the factory to be outsourced. In addition, the insurance for the increasing production should increase as well. Our production value increases rapidly, so we need more insurance to keep our valuable assets safety".

"Service in products becomes a new approach to attract customers. From our investigation, customers are satisfied with our localization strategy that they could easily contact our local service partners to solve their problems when driving our company's automobile. Therefore, we continue to cooperate with local advanced producer service to help us attract more customers and cultivate customer loyalty".

The high level of manufacturing production technique affects the upgrading of advanced producer services as well. As manufacturers (HON.4) who illustrated this:

"We encourage producer service to upgrade synchronously with us so that we could sign strategic contract with high-quality servicer... we invest large amounts of money in RED to upgrading our product, and service in products could not be neglected in competition which we require our service partners to upgrade their service products".

Similarly, is a quotation from related advanced producer services (LOG.2) who made statements:

"We followed the changes with our partners. When we enlarged our transportation team with more vehicles and drivers, we were in debt. Fortunately, we overcome the difficulty when we successfully took the contracts of manufacturers ... Now we are one of the top 5 logistics companies in southern China". 


\subsection{Process of Industrial Diversity Integrated Manufacturing Development with Advanced Producer Service Development}

There are four patterns of the process of industrial diversity from the data. The first one is competitive selection. Manufacturers adopt public threshold and evaluation systems on enterprise size, business capability, and credibility to select service providers. As the standard for partnership selection is clear and public, not only local advanced producer services, but also foreign advanced producer services agglomerate around automobile manufacturer in Guangzhou to compete for the service contracts. Even though the cooperation is built up, the regular evaluation and irregular inspections from manufacturers would operate to keep the service high quality. Usually, manufacturers do regular questionnaires on sectorial satisfaction for service. If they find their employers are not satisfied generally with the services' work, they would establish an investigation group to evaluate the servicer again, communicate with the servicer to improve their service quality or consider adjusting or canceling the contracts. Therefore, numerous advanced producer services grow up to meet the demands of increasing outsource service.

The second pattern is strategic partnership cooperation. Manufacturers intend to maintain stability in cooperation through signing long-term contracts for outsourcing producer service, signing strategic cooperation memorandum for risk and profits share, or cooperative investing in joint research and projects. These strategic partnerships enhance service capability and influence in global competition. Therefore, it is clear to classify the level of advanced producer services by the type of corporation contract. However, each level of services has made great contributions to local employments. Manufacturers could also lower the negotiation cost and reduce the uncertainty with advanced producer service partners.

The third pattern is joint-venture in service providers. This joint-venture is different from the second pattern on joint research and projects, as this joint-venture in services is building up a new company with existing service partners. This pattern is common in advertisement and logistics service industry in Guangzhou. With more outsourcing service relating to production procedure, manufacturers intend to ensure the confidentiality of service content and require service partner to offer exclusive rights for individual service, which is difficult to accomplish by the existing service system. In this context, manufacturers would be willing to build up branches solely for advanced producer service. To lower the cost and avoid decentralization of operation, manufacturers generally cooperate with existing service partner to establish new company for solely service. An example is illustrated as follows from advertising companies (ADV.1):

"Honda in Guangzhou is our only customer and the main reason for our company's establishment. We have a close contact with Honda. One of our bosses is from Honda in Japan. Regularly we participate in some important meetings and offer our opinions on consumers' latest requirements, so that they (manufacturers) will be able to grasp precisely the market demand and adjust their product design. We plan to attract other customers in the future, but now the advertisement task from Honda is totally enough for our profits".

The fourth pattern is proximal spatial distribution. Manufacturers prefer advanced producer service to set up branches inside or around the plants to communicate directly and immediately. Producer services intend to locate near the manufacturers if the cost is acceptable for more possibility to access to informal information. Take one example from the logistics partner (LOG.1).

"We have our small workshop in the plant and sometimes would get the invitation to participate in some important meetings with manufactures on the research discussion of new products ... We would also join the dinner with manufacturers... Then we would know inadvertently the future development trend of our customers and adjust our serving strategy to get the contracts more easily."

Under certain conditions, manufacturing companies would send some engineers or technical experts to strategic partners to provide some guidance on advanced producer services. The approaches to interactions between manufacturing and advanced producer service are diversified. 


\section{Discussions and Conclusions}

This study explored the role of manufacturing in sustainable economic development from the perspective of industrial upgrading and industrial diversity. The empirical materials from the automobile industry and advanced producer service in Guangzhou highlighted two sides. First, our findings confirmed the importance of manufacturing development for advanced producer services and the importance of these industrial interactions for industrial upgrading. The upgrading of manufacturing boosts the upgrading of advanced producer service through the competitive mechanism, the types of cooperation and various interaction approaches. Open and clear competitive mechanisms attract global services as well as local services. Different cooperation contracts represent different degree of cooperation which affects the level and quality of services providing. Long term contract with strategic partnership is beneficial for regional service industry to keep pace with advanced manufacturing development. Second, this research investigated the mechanism of industrial interactions more carefully at firm level. These industrial interactions between manufacturing and advanced producer service enriched the present understanding of industrial diversity. In Guangzhou, there are some local services which provide low level services and some higher services which built up strategic partnership with automobile manufacturers. Various levels of service companies contributed industrial diversity in the city. This diversified knowledge spillover is associated with technological innovation which is beneficial for sustainable economic development.

This exploration of manufacturing's impact on industrial development advances our understanding of economic sustainability to some degree. It is particularly enlightening in the situation of service economy in most of world cities. In Guangzhou, the processes of industrialization and tertiarization happened together. The role of production is still essential for urban sustainable development. The research findings support further that, in Chinese background, the main customer for advanced producer service is still manufacturing [88]. The upgrading of advanced producer service could not develop without the increasing demands of manufacturing. In addition, the findings also further our understanding of the importance of enterprises strategy of localization. The strategy of localization including outsourcing advanced producer services to local actors is significant for industrial diversity with diversified knowledge communication and innovation. Especially for multinational companies, the service outsourcing would bring more industrial cooperation and knowledge spillover where economic development could keep active growth. This positive localization strategy of enterprises is influenced by the regional asset and industrial environment which urban municipalities need to seriously consider [89].

In view of existing knowledge, although the presented result tried to answer the mechanism and process of the role of manufacturing in sustainable economic development from the perspective of industrial upgrading and diversity, it is inadequate to capture all the important features of role of manufacturing in economic sustainability and there are still other perspectives to investigate. The theory will be applicable to a range of cases in diverse fields and in different cultural settings, which is the limit of this research. However, it still inspires researchers to investigate the trend.

Among these results, there are more topics to be discussed further, including an industrial balance of agricultural and industrial production; industrial innovation; resource efficiencies; and a business model for sustainability and a comparison research with other world cities, which have not been done by this paper. In terms of policy implications, manufacturing intersecting in coordination with advanced producer services clearly stands out. It is necessary for governments and public agencies to promote industrial cohesions to stimulate the upgrading of industrial interaction. World cities need a balance between industrial specialization and diversification. Enterprises, the active actors in the economic network, could take more responsibilities in promoting the strategy of sustainable development by enhancing their green production ability and diversified highly efficient services [90].

Author Contributions: This reported research was designed by W.L. and D.X. together since many years ago. The idea and the empirical study were designed and conducted by W.L. who also wrote the first draft. During the review process, X.H. and W.L. refined the manuscript together. 
Funding: This research was funded by the National Natural Science Foundation of China (No. 41320104001) and the Special Fund Project of the Basic Research Service of Sun Yat-Sen University (No.17lgjc04).

Acknowledgments: The authors thank the receiving editor and the anonymous reviewers whose thoughtful critique helped to improve the paper. The authors also thank all the interviewees, especially Mr. Zhang zhanwei for the assistance of the research.

Conflicts of Interest: The authors declare no conflict of interest. The founding sponsors had no role in the design of the study; in the collection, analyses, or interpretation of data; in the writing of the manuscript, and in the decision to publish the results.

\section{Appendix A}

Table A1. Main Interview Questions.

\begin{tabular}{|c|c|}
\hline No. & Interview Outline for Automobile Manufacturers \\
\hline 1 & What is your company's status in the industry in Guangzhou? \\
\hline 2 & What are your company's advantageous competitions in the national and global market? \\
\hline 3 & $\begin{array}{l}\text { What's your attitude towards the relationship between production and sustainable } \\
\text { economic development? }\end{array}$ \\
\hline 4 & $\begin{array}{l}\text { What kinds of factors would influence the upgrading of industrial technique? Please } \\
\text { provide two or more examples and briefly describe them. }\end{array}$ \\
\hline 5 & $\begin{array}{l}\text { What kinds of advanced producer services would you prefer to outsource? Why? Please } \\
\text { provide two or more examples and briefly describe them. }\end{array}$ \\
\hline 6 & $\begin{array}{l}\text { Do you change your service partners? Why? Please provide two or more examples and } \\
\text { briefly describe them. }\end{array}$ \\
\hline 7 & $\begin{array}{l}\text { What kinds of factors would influence your decision on service partners? Please provide } \\
\text { two or more examples and briefly describe them. }\end{array}$ \\
\hline 8 & $\begin{array}{l}\text { What kinds of collaborations would you operate with other industrial actors? Any on } \\
\text { economic sustainability? Please provide two or more examples and briefly describe them. }\end{array}$ \\
\hline No. & Interview Outline for Advanced Producer Services \\
\hline 1 & What is your company's status in the industry in Guangzhou? \\
\hline 2 & What are your company's advantageous competitions in the national and global market? \\
\hline 3 & $\begin{array}{l}\text { What's your attitude towards the relationship between service and sustainable economic } \\
\text { development? }\end{array}$ \\
\hline 4 & $\begin{array}{l}\text { What kinds of factors would influence the upgrading of service technique? Please provide } \\
\text { two or more examples and briefly describe them. }\end{array}$ \\
\hline 5 & $\begin{array}{l}\text { How would you interact with automobile manufacturers? Please provide two or more } \\
\text { examples and briefly describe them. }\end{array}$ \\
\hline 6 & $\begin{array}{l}\text { How often would you interact with automobile manufacturers? Why? Please provide two } \\
\text { or more examples and briefly describe them. }\end{array}$ \\
\hline 7 & $\begin{array}{l}\text { What kinds of factors would influence your service with manufactures? Please provide } \\
\text { two or more examples and briefly describe them. }\end{array}$ \\
\hline 8 & $\begin{array}{l}\text { What kinds of collaborations would you operate with other industrial actors? Any on } \\
\text { economic sustainability? Please provide two or more examples and briefly describe them. }\end{array}$ \\
\hline
\end{tabular}




\section{Appendix B}

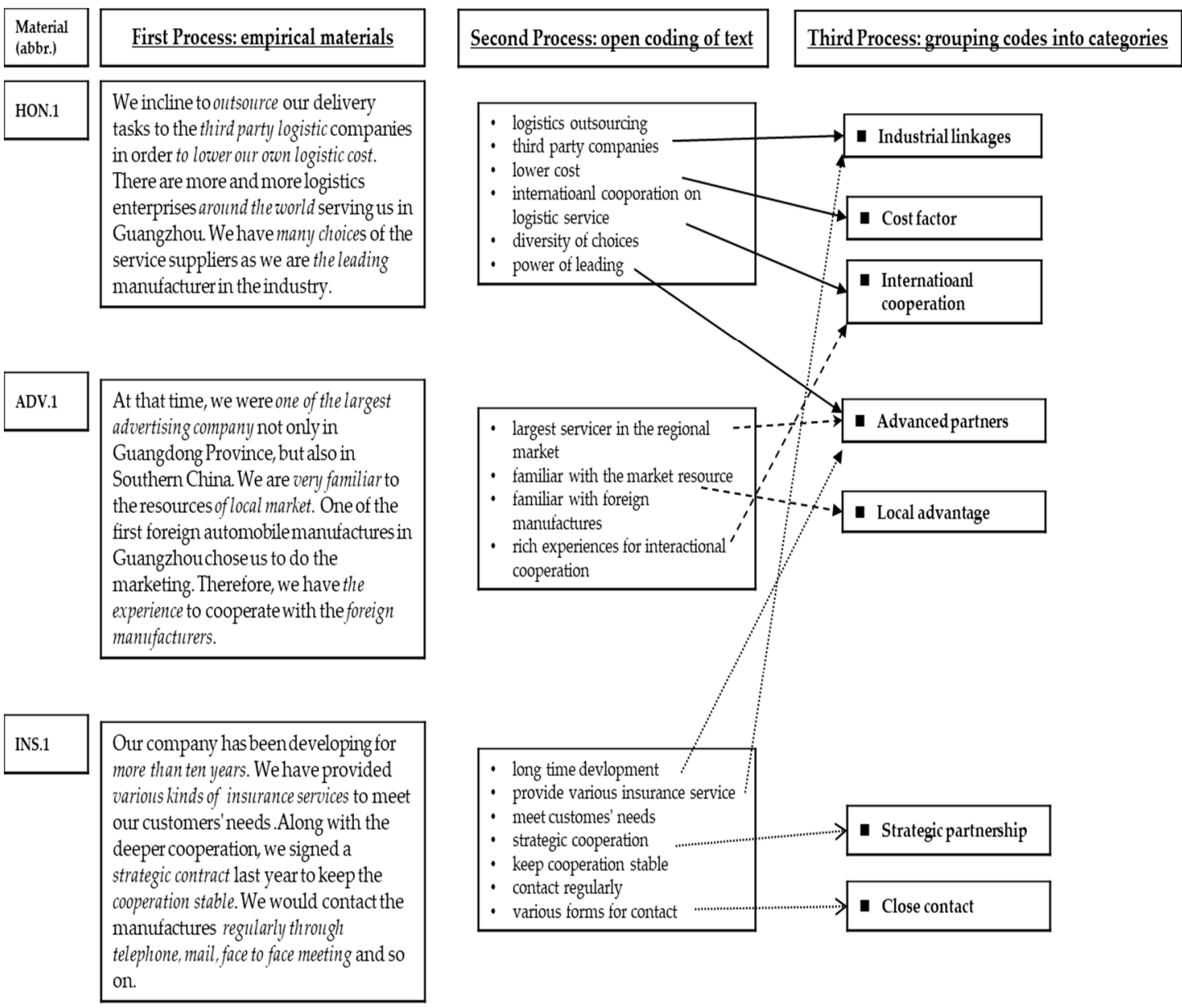

Figure A1. Main Sample of Summarizing Paraphrases of Core Characteristics Coding in GTM Process. (Source: made by authors).

\section{Appendix C}

Table A2. Main Coding Results of Categories, Concepts and Focus Codes.

\begin{tabular}{|c|c|c|}
\hline Categories & Concepts & Codes \\
\hline \multirow{3}{*}{$\begin{array}{l}\text { Incentive for } \\
\text { industrial interaction }\end{array}$} & Demand for production expansion & $\begin{array}{l}\text { Increase of production output } \\
\text { Increase of product sales } \\
\text { Expansion of assembly line } \\
\text { Advances in production technique }\end{array}$ \\
\hline & $\begin{array}{l}\text { Requirement for market } \\
\text { competition }\end{array}$ & $\begin{array}{l}\text { Competitiveness for service during production } \\
\text { Competitiveness for after-sales service } \\
\text { Competitiveness for production technique }\end{array}$ \\
\hline & Localization strategy & $\begin{array}{l}\text { Multichannel integration into the local market } \\
\text { Diversified products for various levels of consumers } \\
\text { Localization of spare part providers } \\
\text { Outsource of advanced producer services }\end{array}$ \\
\hline
\end{tabular}


Table A2. Cont.

\begin{tabular}{|c|c|c|}
\hline Categories & Concepts & Codes \\
\hline \multirow{4}{*}{$\begin{array}{l}\text { Process of industrial } \\
\text { interaction }\end{array}$} & Competitive selection & $\begin{array}{l}\text { Scale threshold } \\
\text { Technical threshold } \\
\text { Cost factor } \\
\text { Regular evaluation } \\
\text { Irregular inspections }\end{array}$ \\
\hline & Strategic partnership & $\begin{array}{l}\text { Sign long-term contracts } \\
\text { Sign strategic cooperation memorandum } \\
\text { Joint research and development }\end{array}$ \\
\hline & Joint-venture investments & $\begin{array}{l}\text { Capital investments with joint-venture services } \\
\text { Technique investments with joint-venture services } \\
\text { Sole investment in subsidiary services }\end{array}$ \\
\hline & Proximity effect & $\begin{array}{l}\text { Regular meetings held in factory } \\
\text { Close contact } \\
\text { Adjacent guidance }\end{array}$ \\
\hline
\end{tabular}

\section{References}

1. The 17 Sustainable Development Goals (SDGs) of the 2030 Agenda for Sustainable Development; Commission on Sustainable Development: New York, NY, USA, 2016.

2. Indicators of Sustainable Development: Guidelines and Methodologies; Commission on Sustainable Development: New York, NY, USA, 2001.

3. Terama, E.; Milligan, B.; Jimenez-Aybar, R.; Mace, G.M.; Ekins, P. Accounting for the environment as an economic asset: Global progress and realizing the 2030 agenda for sustainable development. Sustain. Sci. 2016, 11, 945-950. [CrossRef]

4. Cohen, M. A systematic review of urban sustainability assessment literature. Sustainability 2017, 9, 2048. [CrossRef]

5. Strezov, V.; Evans, A.; Evans, T.J. Assessment of the economic, social and environmental dimensions of the indicators for sustainable development. Sustain. Dev. 2017, 25, 242-253. [CrossRef]

6. Can, U.; Alatas, B. Big social network data and sustainable economic development. Sustainability 2017, 9, 2027. [CrossRef]

7. Liu, Y.; Liang, Y.; Ma, S.; Huang, K.; Liu, Y.; Liang, Y.; Ma, S.; Huang, K. Divergent developmental trajectories and strategic coupling in the pearl river delta: Where is a sustainable way of regional economic growth? Sustainability 2017, 9, 1782. [CrossRef]

8. Bandyopadhyay, S. Evaluating sustainable economic development. Clean Technol. Environ. Policy 2017, 19, 1815-1816. [CrossRef]

9. Friedmann, J. The world city hypothesis. Dev. Chang. 1986, 17, 69-83. [CrossRef]

10. Friedmann, J.; Wolff, G. World city formation: An agenda for research and action. Int. J. Urban Reg. Res. 1982, 6, 309-344. [CrossRef]

11. Sassen, S. Global financial centers. Foreign Aff. 1999, 78, 75-87. [CrossRef]

12. Sassen, S. The Global City: New York, London, Tokyo; Princeton University Press: Princeton, NJ, USA, 2013; pp. 501-502.

13. Li, Z.Y.; Dawood, S.R.S.; Zhang, X.X. An appraisal of Asia-Pacific cities as control and command centres embedded in world city network. Eng. Technol. Appl. Sci. Res. 2017, 7, 1879-1882.

14. Neal, Z. Differentiating centrality and power in the world city network. Urban Stud. 2011, 48, $2733-2748$. [CrossRef]

15. Castells, M. Rise of the Network Society; Blackwell Publishers: Hoboken, NJ, USA, 2000; pp. 389-414.

16. Liu, X.; Derudder, B.; Wu, K. Measuring polycentric urban development in China: An intercity transportation network perspective. Reg. Stud. 2016, 50, 1302-1315. [CrossRef]

17. Li, Y.; Phelps, N. Megalopolis unbound: Knowledge collaboration and functional polycentricity within and beyond the Yangtze River delta region in China, 2014. Urban Stud. 2018, 55, 443-460. [CrossRef]

18. Zhao, M.; Derudder, B.; Huang, J. Examining the transition processes in the Pearl River delta polycentric Mega-City region through the lens of corporate networks. Cities 2017, 60, 147-155. [CrossRef] 
19. Zhang, X.; Kloosterman, R.C. Connecting the "Workshop of the World": Intra- and extra-service networks of the Pearl River delta City-Region. Reg. Stud. 2016, 50, 1069-1081. [CrossRef]

20. Krätke, S. How manufacturing industries connect cities across the world: Extending research on 'multiple globalizations'. Glob. Netw. 2014, 14, 121-147. [CrossRef]

21. Martinus, K.; Tonts, M. Powering the world city system: Energy industry networks and interurban connectivity. Environ. Plan. A 2015, 47, 1502-1520. [CrossRef]

22. Lin, G. Toward a post-socialist city? Economic tertiarization and urban reformation in the Guangzhou metropolis, China. Eurasian Geogr. Econ. 2004, 45, 18-44. [CrossRef]

23. Jiang, H.Y.; Yang, Q.S. Analysis on the importance of manufacturing industries in the process of urban economic transition: Taking Guangzhou as an example. Econ. Geogr. 2012, 8, 012. [CrossRef]

24. Dandan, D.; Chunshan, Z. Study on the characteristics of the industrial transformation of Guangzhou since 1995. Econ. Geogr. 2012, 11, 81-88. [CrossRef]

25. Guangzhou Burenu of Statistics. Guangzhou Statistical Yearbook 2016; China Statistics Press: Beijing, China, 2016. (In Chinese)

26. Glaser, B.G.; Strauss, A.L. The Discovery of Grounded Theroy: Strategies for Qualitative Research; Aldine: Chicago, IL, USA, 1967.

27. Ness, B.; Urbel-Piirsalu, E.; Anderberg, S.; Olsson, L. Categorising tools for sustainability assessment. Ecol. Econ. 2007, 60, 498-508. [CrossRef]

28. Shi, X.; Zhang, X.; Dong, C.; Wen, S. Economic performance and emission reduction of supply chains in different power structures: Perspective of sustainable investment. Energies 2018, 11, 983. [CrossRef]

29. Shi, X.; Qian, Y.; Dong, C. Economic and environmental performance of fashion supply chain: The joint effect of power structure and sustainable investment. Sustainability 2017, 9, 961. [CrossRef]

30. Kesharwani, R.; Sun, Z.Y.; Dagli, C. Biofuel supply chain optimal design considering economic, environmental, and societal aspects towards sustainability. Int. J. Energy Res. 2018, 42, 2169-2198. [CrossRef]

31. Stamford, L.; Greening, B.; Azapagic, A. Life cycle environmental and economic sustainability of stirling engine micro-CHP systems. Energy Technol. 2018, 6, 1119-1138. [CrossRef]

32. Wang, S.S.; Li, R.R. Toward the coordinated sustainable development of urban water resource use and economic growth: An empirical analysis of Tianjin City, China. Sustainability 2018, 10, 13. [CrossRef]

33. Stougie, L.; Giustozzi, N.; Van Der Kooi, H.; Stoppato, A. Environmental, economic and exergetic sustainability assessment of power generation from fossil and renewable energy sources. Int. J. Energy Res. 2018, 42, 2916-2926. [CrossRef]

34. Sarker, S.; Bhuyan, M.A.H.; Rahman, M.M.; Islam, M.A.; Hossain, M.S.; Basak, S.C.; Islam, M.M. From science to action: Exploring the potentials of blue economy for enhancing economic sustainability in Bangladesh. Ocean Coast. Manag. 2018, 157, 180-192. [CrossRef]

35. Lo, A.Y.; Liu, S.W. Towards sustainable consumption: A socio-economic analysis of household waste recycling outcomes in Hong Kong. J. Environ. Manag. 2018, 214, 416-425. [CrossRef] [PubMed]

36. Wang, C.; Wang, L.; Dai, S.F. An Indicator approach to industrial sustainability assessment: The case of China's capital economic circle. J. Clean Prod. 2018, 194, 473-482. [CrossRef]

37. Rumyantsev, A.A. Research and innovation activity in the region as a driver of its sustainable economic development. Econ. Soc. Chang. Facts Trends Forecast 2018, 11, 84-99. [CrossRef]

38. Luken, R.; Castellanos-Silveria, F. Industrial transformation and sustainable development in developing countries. Sustain. Dev. 2011, 19, 167-175. [CrossRef]

39. Yun, J.J.; Jung, K.; Yigitcanlar, T. Open innovation of James watt and Steve jobs: Insights for sustainability of economic growth. Sustainability 2018, 10, 16. [CrossRef]

40. Hameed, T.; Von Staden, P.; Kwon, K.S. Sustainable economic growth and the adaptability of a national system of innovation: A socio-cognitive explanation for South Korea's mired technology transfer and commercialization process. Sustainability 2018, 10, 26. [CrossRef]

41. Meng, B.; Chi, G.T. Evalution index system of green industry based on maximum information content. Singap. Econ. Rev. 2018, 63, 229-248. [CrossRef]

42. Shao, S.A.; Luan, R.R.; Yang, Z.B.; Li, C.Y. Does directed technological change get greener: Empirical evidence from Shanghai's industrial green development transformation. Ecol. Indic. 2016, 69, 758-770. [CrossRef] 
43. Liu, G.Y.; Hao, Y.; Zhou, Y.; Yang, Z.F.; Zhang, Y.; Su, M.R. China's low-carbon industrial transformation assessment based on logarithmic mean divisia index model. Resour. Conserv. Recycl. 2016, 108, 156-170. [CrossRef]

44. Fu, J.P.; Xiao, G.R.; Guo, L.L.; Wu, C.Y. Measuring the dynamic efficiency of regional industrial green transformation in China. Sustainability 2018, 10, 19. [CrossRef]

45. Zhou, X.Y.; Lei, K.; Meng, W.; Khu, S.T. Industrial structural upgrading and spatial optimization based on water environment carrying capacity. J. Clean Prod. 2017, 165, 1462-1472. [CrossRef]

46. Gu, J.J.; Guo, P.; Huang, G.H.; Shen, N. Optimization of the industrial structure facing sustainable development in resource-based city subjected to water resources under uncertainty. Stoch. Environ. Res. Risk Assess. 2013, 27, 659-673. [CrossRef]

47. Chiang, S.-H. The effects of industrial diversification on regional unemployment in Taiwan: Is the portfolio theory applicable? Ann. Reg. Sci. 2009, 43, 947-962. [CrossRef]

48. Mizuno, K.; Mizutani, F.; Nakayama, N. Industrial diversity and metropolitan unemployment rate. Ann. Reg. Sci. 2006, 40, 157-172. [CrossRef]

49. Izraeli, O.; Murphy, K.J. The effect of industrial diversity on state unemployment rate and per capita income. Ann. Reg. Sci. 2003, 37, 1-14. [CrossRef]

50. Malizia, E.E.; Ke, S. The influence of economic diversity on unemployment and employment stability. J. Reg. Sci. 1993, 33, 221-235. [CrossRef]

51. Kort, J.R. Regional economic instability and industrial diversification in the U.S. Land Econ. 1981, 57, 596-608. [CrossRef]

52. Rodgers, A. Some aspects of industrial diversification in the United States. Econ. Geogr. 1957, 33, 16-30. [CrossRef]

53. Geng, Y.; Cote, R. Diversity in industrial ecosystems. Int. J. Sustain. Dev. World Ecol. 2007, 14, $329-335$. [CrossRef]

54. Brown, L.; Greenbaum, R.T. The role of industrial diversity in economic resilience: An empirical examination across 35 years. Urban Stud. 2017, 54, 1347-1366. [CrossRef]

55. Fornahl, D.; Guenther, C. Persistence and change of regional industrial activities: The impact of diversification in the German machine tool industry. Eur. Plan. Stud. 2010, 18, 1911-1936. [CrossRef]

56. Meerow, S.; Newell, J.P. Resilience and complexity a bibliometric review and prospects for industrial ecology. J. Ind. Ecol. 2015, 19, 236-251. [CrossRef]

57. Siegel, P.B.; Johnson, T.G.; Alwang, J. Regional economic diversity and diversification. Growth Chang. 1995, 26, 261-284. [CrossRef]

58. Ernst, D. Catching-up crisis and industrial upgrading: Evolutionary aspects of technological learning in Korea's electronics industry. Asia Pac. J. Manag. 1998, 15, 247-283. [CrossRef]

59. Chen, L.C.; Chien, S.S. Industrial Upgrading and interaction between the advanced small south and China: The case of Taiwan's machine tool industry. Area Dev. Policy 2017, 2, 91-107. [CrossRef]

60. Park, S.H.; Chan, K.S. A cross-country input-output analysis of intersectoral relationships between manufacturing and services and their employment implications. World Dev. 1989, 17, 199-212. [CrossRef]

61. Hansen, N. Do producer services induce regional economic development? J. Reg. Sci. 1990, 30, 465-476. [CrossRef]

62. Rodriguez, N.P.; Feagin, J.R. Urban specialization in the world-system an investigation of historical cases. Urban Aff. Rev. 1986, 22, 187-220. [CrossRef]

63. Lughod, J.L.A. New York, Chicago, Los Angeles; University of Minnesota Press: Minneapolis, MN, USA, 1999.

64. Hill, R.C.; Kim, J.W. Global cities and developmental states: New York, Tokyo and Seoul. Urban Stud. 2000, 37, 2167-2195. [CrossRef]

65. Fujita, K.; Hill, R.C. Global toyotaism and local development. Int. J. Urban Reg. Res. 1995, 19, 7-22. [CrossRef]

66. Wang, C.H. Taipei as a global city: A theoretical and empirical examination. Urban Stud. 2003, 40, 309-334. [CrossRef]

67. Olds, K.; Yeung, H. Pathways to global city formation: A view from the developmental city-state of Singapore. Rev. Int. Polit. Econ. 2004, 11, 489-521. [CrossRef]

68. Krätke, S. Global pharmaceutical and biotechnology firms' linkages in the world city network. Urban Stud. 2014, 51, 1196-1213. [CrossRef] 
69. Chubarov, I.; Brooker, D. Multiple pathways to global city formation: A Functional approach and review of recent evidence in China. Cities 2013, 35, 181-189. [CrossRef]

70. Shi, Y.; Hamnett, C. The Potential and prospect for global cities in China: In The context of the world system. Geoforum 2002, 33, 121-135. [CrossRef]

71. Wu, F. The global and local dimensions of place-making: Remaking Shanghai as a world city. Urban Stud. 2000, 37, 1359-1377. [CrossRef]

72. Tao, Z. Hong Kong: From an industrialised city to a centre of manufacturing-related services. Urban Stud. 2002, 39, 2345-2358. [CrossRef]

73. Yusuf, S.; Wu, W. Pathways to a world city: Shanghai rising in an era of globalisation. Urban Stud. 2002, 39, 1213-1240. [CrossRef]

74. Lia, Z.; Wu, F. Socioeconomic transformations in Shanghai (1990-2000): Policy impacts in global-nationallocal contexts. Cities 2006, 23, 250-268. [CrossRef]

75. Wei, Y.D.; Yu, D.D.U.E. State policy and the globalization of Beijing: Emerging themes. Habitat Int. 2006, 30, 377-395. [CrossRef]

76. Strauss, A.; Corbin, J.M. Basics of qualitative research: Grounded theory procedures and techniques. Mod. Lang. J. 2006, 77, 129. [CrossRef]

77. Stumpf, T.S.; Sandstrom, J.; Swanger, N. Bridging the gap: Grounded theory method, theory development, and sustainable tourism research. J. Sustain. Tour. 2016, 24, 1691-1708. [CrossRef]

78. Wuelser, G.; Pohl, C. How researchers frame scientific contributions to sustainable development: A typology based on grounded theory. Sustain. Sci. 2016, 11, 789-800. [CrossRef]

79. Corbin, J.M.; Strauss, A.L. Basics of Qualitative Research: Techniques and Procedures For Developing Grounded Theory; Sage: London, UK, 1998; p. 129.

80. Charmaz, K. Constructing Grounded Theory: A Practical Guide through Qualitative Analysis; Sage Publications Ltd.: London, UK, 2006.

81. Charmaz, K. Constructivist grounded theory. J. Posit. Psychol. 2017, 12, 299-300. [CrossRef]

82. Allen, N.; Davey, M. The value of constructivist grounded theory for built environment researchers. J. Plan. Educ. Res. 2018, 38, 222-232. [CrossRef]

83. O'connor, K. Global city regions and the location of logistics activity. J. Transp. Geogr. 2010, 18, $354-362$. [CrossRef]

84. Taylor, P.J. Specification of the world city network. Geogr. Anal. 2001, 33, 181-194. [CrossRef]

85. Charmaz, K. The legacy of anselm strauss in constructivist grounded theory. In Studies in Symbolic Interaction; Denzin, N.K., Salvo, J., Washington, M., Eds.; Emerald Group Publishing Limited: Bingley, UK, 2008; Volume 32, pp. 127-141.

86. Jones, M.; Alony, I. Guiding the use of grounded theory in doctoral studies-An example from the Australian film industry. Int. J. Dr. Stud. 2011, 6, 95-114. [CrossRef]

87. Xu, J.; Yeh, A.G.O. Guangzhou. Cities 2003, 20, 361-374. [CrossRef]

88. Cheng, D.; Daniels, P.W. What's so special about China's producer services? An input-output analysis. China World Econ. 2014, 22, 103-120. [CrossRef]

89. Crescenzi, R.; Pietrobelli, C.; Rabellotti, R. Regional strategic assets and the location strategies of emerging countries' multinationals in Europe. Eur. Plan. Stud. 2016, 24, 645-667. [CrossRef]

90. Fernando, L.; Evans, S. Case studies in transformation towards industrial sustainability. Int. J. Knowl. Syst. Sci. 2015, 6, 1-17. [CrossRef]

(C) 2018 by the authors. Licensee MDPI, Basel, Switzerland. This article is an open access article distributed under the terms and conditions of the Creative Commons Attribution (CC BY) license (http://creativecommons.org/licenses/by/4.0/). 